\title{
Rolling Pampas agroecosystem: which landscape attributes are relevant for determining bird distributions?
}

\author{
Federico Weyland ${ }^{1,3^{*}}$, Jacques Baudry ${ }^{2}$ and Claudio M Ghersa ${ }^{1}$
}

\begin{abstract}
Background: Agricultural intensification is among the main factors affecting biodiversity. The Rolling Pampas of Argentina have undergone through a process of landscape transformation and agricultural intensification that altered avian diversity patterns. Grassland area loss is argued to be the main reason for grassland bird species declines, but there is a lack of studies that compare cropland vs. pastures including other landscape features as determinants of species richness and distribution. Also, it is needed to understand how these relations are modified at different spatial scales. In this study, we explored how species are associated to different landscape attributes and elements like land use, roadside vegetation, trees, homesteads, and water bodies. Our aim was to explore how bird species are associated to the new elements of the Pampas agroecosystem at different spatial scales to reveal which are important for avian management.

Results: We ran field surveys covering a range of land use and landscape complexity, defined by the variety of component features. We performed canonical correspondence and diversity partition analyses to determine the association of species with land use, landscape complexity, and particular anthropogenic elements. Our results show that land use type is an important driver of bird species distributions, but it is also controlled by the presence of trees, houses, and water bodies that provide nesting and food resources. Simple landscapes have higher species turnover rates (beta diversity) than complex ones with similar gamma diversity, demonstrating that the effect of landscape simplification on bird diversity differs across spatial scales, leading to different possible management and conservation strategies

Conclusions: New approaches are needed to manage agroecosystems for avian conservation. We need to take pragmatic approaches, and in highly disturbed ecosystems, anthropic elements have to be included as constituent parts of the system.
\end{abstract}

Keywords: Biodioversity; Argentina; Avian conservation; Landscape planning

\section{Background}

Loss of biodiversity in agroecosystems is a global concern since the last decades (Chapin et al. 2000). Land cover change and landscape simplification as consequences of land use intensification are factors identified as responsible for biodiversity loss (Benton et al. 2003;

\footnotetext{
* Correspondence: fweyland@agro.uba.ar

'IFEVA/CONICET - Departamento de Recursos Naturales y Ambiente, Facultad de Agronomía, Universidad de Buenos Aires, Av. 4453, San Martín, Buenos Aires C1417DSE, Argentina

${ }^{3}$ Present Address: Grupo de Agroecosistemas y Paisajes Rurales, Recursos Naturales y Gestión Ambiental, INTA - Instituto Nacional de Tecnología Agropecuaria - EEA, Balcarce CC 276, Balcarce 7620, Argentina Full list of author information is available at the end of the article
}

Tscharntke et al. 2005). Agroecosystems, however, can harbor a noteworthy biodiversity if properly managed (Pimentel et al. 1992). For that reason, we need to develop management plans aiming at obtaining agricultural production and at the same time minimizing its negative effects on biodiversity.

Landscape transformation by agriculturization leads to the creation of novel ecosystems, where new combinations of species and abiotic conditions are set (Hobbs et al. 2006). The Pampas grasslands of Argentina is one of the regions where agriculturization dramatically changed the landscape during the last two centuries (Ghersa and León 2001). This process lead to the 
reduction of grassland area and the introduction of the common elements of an agroecosystem: a network of roads and their roadsides, urbanization, and alteration of the presence and nature of water bodies (ponds, ditches, etc.). A conspicuous change was caused by the introduction of trees. Trees were introduced by European settlers to provide shade and delimitate the properties. Nowadays, many species have naturalized and invaded roadsides and riversides (Ghersa et al. 2002). In abandoned houses, secondary succession produces small ( $<5$ ha) woodlots with a noticeable tree species richness (Chaneton et al. 2012).

Agriculturization of the Pampas affected biodiversity patterns across taxa (Suárez et al. 2000; Medan et al. 2011). In the case of birds, loss of grassland area is one of the main factors for the decline in species richness and abundance (Filloy and Bellocq 2007; Schrag et al. 2009; Cerezo et al. 2011; Azpiroz et al. 2012). The range of some species, like pampas meadowlark (Sturnella defillipii Bonaparte, 1850), white and black monjita (Xolmis dominicanus Vieillot, 1823), and pipits (Anthus spp. Vieillot, 1818), was reduced leading them to levels of conservation concern or regional extinction (Collar and Wege 1995; Krapovickas and Di Giacomo 1998; Gabelli et al. 2004).

Other attributes and elements of the agroecosystem, such as urbanization, artificial water bodies, and trees, also affected bird diversity, though their influence was less explored. Urbanization, as in other parts of the world, impoverished and homogenized bird fauna (Leveau and Leveau 2005; Faggi et al. 2006; Garaffa et al. 2009). Natural and artificial water bodies provide refuge for many species of birds (Shnack et al. 2000). Tree invasion in roadsides and riversides, on the other hand, negatively affected grassland species, but at the same time favored a group of species that colonized from surrounding regions, like Swainson's hawk (Buteo swainsoni Bonaparte, 1838), picazuro pigeon (Patagioenas picazuro Temminck, 1813), flickers (Colaptes spp. Vieillot, 1818), and great kiskadee (Pitangus sulphuratus Linnaeus, 1766) (Comparatore et al. 1996; Codesido et al. 2011). Most of these species were already common species with no conservation concern.

Land use type (cropland vs. pasture) has received more attention than the other attributes and elements of the agroecosystem in relation toward its effect on biodiversity of the Pampas. Moreover, studies that evaluate the relative importance of the different landscape attributes to guide management plans for biodiversity conservation are still lacking. Previous studies showed that the landscape complexity rendered by particular configurations of trees, water bodies, and homesteads provides conditions for greater bird diversity, and may be more important than land use type (Weyland et al. 2012). Landscape complexity can not only contribute to species richness but also change the species distribution as the resource supply changes, particularly nesting and food. Furthermore, the effect of landscape complexity on biodiversity may differ across spatial scales (Flohre et al. 2011). Poggio et al. (2010), for example, found that more complex agricultural landscapes did not increase alpha (local) diversity of weeds in fencerows, but it increased gamma (regional) diversity through species turnover (beta diversity). It has been demonstrated for other taxa as well that biodiversity patterns at the local scale do not extrapolate to the regional scale (Gering et al. 2003; Fleishman et al. 2003). This leads to different patterns of species richness and composition depending upon the scale of landscape simplification considered. For this reason, finding how landscape attributes at different spatial scales affect bird distributions is important when discussing management plans to favor biodiversity (Tscharntke et al. 2005).

In this study, we explored how bird species are associated to the new attributes of the Rolling Pampas agroecosystem (agricultural land use, trees, homesteads) at local and landscape scales to reveal which are important for avian conservation and management. We hypothesize that (1) bird species distributions will be determined by the landscape elements that provide food and nesting resources, and (2) species assemblages will vary with landscape complexity depending upon the spatial scale.

\section{Methods}

\section{Study area}

This study was carried out in a $23,296-\mathrm{km}^{2}$ area of the Rolling Pampa, one of the ecological units that are part of the Pampas region (Figure 1a,b). The Pampas region originally was a temperate grassland, characterized by the absence of trees and generally flat topography (Soriano 1991). Since the mid-1800s, this region has been severely transformed by agricultural and grazing activities (Ghersa and León 2001). The European colonization also introduced changes in the physiognomy of the vegetation with the introduction of trees. Some of these species, like Gleditsia triacanthos L., Morus alba L., Melia azedarach L. 1753, Broussonetia papyrifera (L.) Vent., and Ligustrum lucidum W.T.Aiton, 1810, invaded roadsides, wastelands, and grassland relicts (Ghersa et al. 2002; Zalba and Villamil 2002). In the last 20 years, the introduction of no-tillage cropping systems and genetically modified crops replaced the mixed grazing-cropping system with permanent agriculture, with an associated increase in the soybean area and a decrease in landscape heterogeneity (Baldi and Paruelo 2008; Aizen et al. 2009). The other main crops in the region are maize and wheat. Today, soybean accounts for nearly $70 \%$ of sown area, whereas maize and wheat account for between 10\% and 15\% each (MDAYP 2010). Pastures and grasslands cover less than $40 \%$ of the 


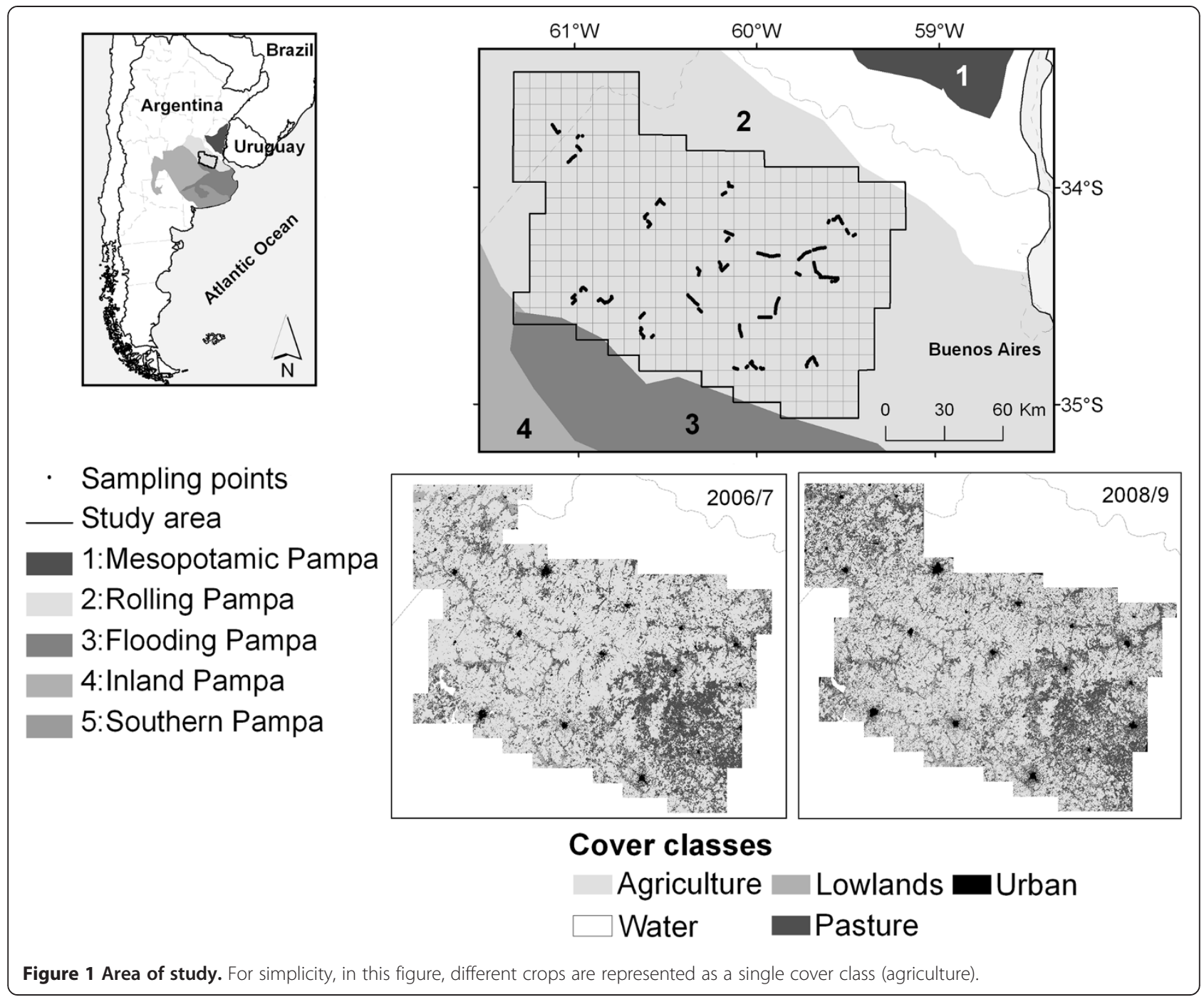

area (Baldi et al. 2006). Cattle grazing is restricted mainly to the Flooding Pampas region, where agriculture is limited by hydrology and soil. Grasslands in this unit are the less fragmented in the Argentinian Pampas (Baldi and Paruelo 2008). The Southern and Inland Pampas are also very agriculturized units, with predominance of soybean, wheat, sunflower, and oats as main crops (MDAYP 2010).

\section{Landscape classification and data collection}

We characterized agricultural landscape at two spatial scales: facet and local. A facet is a combination of different ecotopes (being these the smaller holistic unit of land) (Zonneveld 1989). For the facet scale, we divided the study area with a grid of $8 \times 8 \mathrm{~km}$ cells (hereafter, facets) $(n=364)$. In our study region, a $64-\mathrm{km}^{2}$ area approximates the facet scale, comprising several farms and different land use type units (ecotopes in our case). We measured landscape attributes in each facet using supervised classified Landsat TM images of two cropping years (2006 and 2008, Figure 1c). This classification identifies seven land use types: water, lowlands, pastures, maize, soybean, wheat, and urban. 'Lowlands' and 'pastures' are differentiated by their topographic position in the landscape. Lowlands are temporally flooded natural grasslands that are found alongside rivers and streams in low positions. Pastures are sown pastures or semi-natural grasslands in higher positions. We randomly selected 39 facets in which we placed sampling points $1 \mathrm{~km}$ apart to ensure independence and avoid double counting (Ralph et al. 1995) (3 to 8 points per facet, $n=237$ ) along secondary dirt roads (Figure $1 \mathrm{~b}$ ). In the facets selected, we also mapped tree lines and woodlots using Google Earth ${ }^{\circledast}$ images, because the supervised classification of Landsat images did not identify woody vegetation as a distinct land cover type.

Each point was visited once during the bird reproductive season of two consecutive years (2007 and 2008) to carry out field surveys. Bird surveys were carried out 
Table 1 Interset correlations of variables with axes of CCAs at local and facet scales

\begin{tabular}{|c|c|c|c|}
\hline Scale & Variable & Axis 1 & Axis 2 \\
\hline & Water (presence/absence) ${ }^{a}$ & -0.528 & 0.159 \\
\hline & 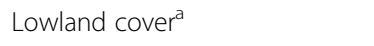 & -0.507 & 0.167 \\
\hline & Pond cover $^{\mathrm{a}}$ & -0.27 & -0.029 \\
\hline & Trees (woodlots and tree lines) ${ }^{a}$ & 0.254 & 0.528 \\
\hline & Pasture cover ${ }^{a}$ & -0.21 & 0.308 \\
\hline & Maize cover & 0.177 & -0.172 \\
\hline & Houses (presence/absence) ${ }^{a}$ & 0.157 & 0.439 \\
\hline & Wheat cover ${ }^{a}$ & 0.135 & -0.361 \\
\hline & Trees (scattered) ${ }^{a}$ & 0.089 & 0.315 \\
\hline \multirow[t]{15}{*}{ Local } & Wood cover & 0.113 & 0.231 \\
\hline & Lawn cover & 0.084 & 0.287 \\
\hline & Cover richness & -0.119 & 0.14 \\
\hline & Stuble cover & 0.116 & -0.11 \\
\hline & Soybean cover & 0.045 & -0.163 \\
\hline & Roadside complexity & -0.082 & -0.033 \\
\hline & Agriculture cover & 0.064 & -0.017 \\
\hline & Bare soil cover & 0.037 & 0.125 \\
\hline & Oats cover & 0.026 & -0.064 \\
\hline & Urban cover & 0.026 & 0.059 \\
\hline & Pasture $^{a}$ & 0.687 & 0.063 \\
\hline & Maize $^{a}$ & -0.56 & -0.175 \\
\hline & Soybean $^{a}$ & -0.5 & -0.072 \\
\hline & Soybean/wheat ${ }^{\mathrm{a}}$ & -0.487 & -0.196 \\
\hline & Tree lines length ${ }^{a}$ & 0.378 & -0.122 \\
\hline \multirow[t]{6}{*}{ Facet } & Number of tree lines ${ }^{a}$ & 0.336 & -0.225 \\
\hline & Urban $^{\mathrm{a}}$ & 0.295 & 0.009 \\
\hline & Number of woodlands ${ }^{a}$ & 0.012 & -0.239 \\
\hline & Woodland area $^{a}$ & 0.172 & -0.119 \\
\hline & Water & -0.139 & -0.004 \\
\hline & Lowland & 0.057 & 0.024 \\
\hline
\end{tabular}

${ }^{a}$ Variables that have the higher correlations swith axes 1 and 2 and are drawn in ordination diagrams in Figures 3, 4 and 5.

using the point count method (Ralph et al. 1995). Surveys were done in the first hours after sunrise (6:00 to 10:30 a.m.) in good weather conditions, and all birds seen or heard during $5 \mathrm{~min}$ in the $350-\mathrm{m}$ radius were counted. This radius was determined based on the field observer's ability to detect individuals and identify the species (G. Rocha, personal communication). At each point, we also measured landscape variables in the $350-\mathrm{m}$ radius (hereafter, local scale) by visual inspection: cover area for each land use type, roadside vegetation condition (spontaneous, grazed, sprayed, cultivated, stubble, ploughed, ditch), and presence of trees (woodlots, tree lines, scattered trees), water bodies, and inhabited houses.

\section{Data analysis}

To determine the association of bird species to landscape attributes, we ran canonical correspondence analyses (CCA). We ran CCAs with variables at local and facet scales using presence/absence data of birds. We removed species that were detected in two or less sites, as the distribution of rare species in the environmental gradient cannot be adequately estimated with CCA (Batista 1991). That way, we kept 77 species for the analyses (Additional file 1: Table S1). The patterns for the rest of the species are discussed not statistically in the corresponding section.

For the local scale CCA, we used 19 environmental variables considered important for determining bird species distributions including the \%cover of the most common land uses, land cover richness (number of different land cover types), and presence/absence of inhabited houses and water bodies (Table 1). For roadsides and trees, we calculated a variable that represents the complexity rendered to the landscape by these elements using a fuzzy logic approach. Fuzzy logic allows combining statements expressed in a natural language using linguistic variables to account for uncertainty and ambiguity in the information. Input variables are combined through logic rules using expert knowledge to give a value in an output variable. We built a fuzzy logic model hypothesizing that the landscape complexity rendered by roadsides depends on the contrast between the vegetation and the main land use in the matrix, its width, and whether or not there are similar land cover types in the landscape. These three input variables were combined to give an output variable that represents the roadside complexity in a scale of 0 to 1 . We built another fuzzy logic model to account for the complexity rendered by woody vegetation. In this model, complexity depends on the combination of presence/absence of tree lines and simple (monospecific) or complex (multispecific with some secondary succession) woodlots. The landscape complexity increases when more of the latter elements are present and is also expressed in a 0 to 1 scale. More details on the methodology are given in Weyland et al. (2012).

For the CCA at the facet scale, we used 11 environmental variables including \%cover of the different land uses identified by the satellite images. We also calculated four variables representing woody vegetation characteristics: total tree line length, number of tree lines, total woodland area, and number of woodlots. In order to determine which ecological trait is important for determining, we identified nesting habitat and trophic groups (Additional file 1: Table S1) following de la Peña (1992). Nesting habitat was identified in the same CCAs at both scales of analysis. Food habit is related to species ecological function, and in agroecosystems, it determines, 
broadly speaking, whether they are crop pests or pest controllers, which is one of the major concerns when managing biodiversity in agroecosystems (Sekercioglu 2006). In order to determine whether the trophic habit determines the distribution of species according to the landscape attributes, we ran CCAs for the trophic groups and the same matrices of environmental variables. For this analysis, we used abundance data as the weight of ecological functions is better attained by abundance than presence/absence of species. The estimation of abundance of individuals is biased in point counts because of differences in detection probabilities among species. To avoid this bias, we corrected our data based on the method proposed by Farnsworth et al. (2002) and based in the capture-recapture model of Zipping (1958). We divided the sampling period in two time intervals 2.5 min each $\left(x_{1}\right.$ and $\left.x_{2}\right)$. The detection probability $(\hat{p})$ is calculated as:

$$
\hat{p}=\frac{x_{1}}{x_{1}-x_{2}}
$$

We summed up observations of all sampling points to have a detection probability of each species and then we estimated abundance $(\widehat{N})$ in the sampling point as

$$
\widehat{N}=\frac{A}{\hat{p}}
$$

where $A$ is observed abundance in the sampling point.

We performed Monte Carlo randomization tests with 100 runs to evaluate the statistical significance of all ordinations.

We performed a diversity partition analysis to determine the species turnover among sites of different landscape complexities (used here indistinctly from heterogeneity). We built a fuzzy logic model to calculate a complexity index based on a combination of six attributes and elements: cover type richness, roadside vegetation complexity, trees as woodlots and tree lines, and presence of scattered trees, houses, and water bodies. The complexity of the landscape increases as more different elements and cover types are present. Using expert knowledge and adjusting the model with empirical data on bird species richness, we combined the six input variables through logic rules to get a complexity index ranging from 0 to 1 (see more details in Weyland et al. 2012). We then divided this local scale landscape complexity gradient in ten levels. The levels of highest landscape complexity had too few points, so we pooled them in a single level ( 0.8 to 1$)$. We calculated gamma and mean alpha bird diversities for the sampling points in each complexity level. Gamma diversity was calculated as the total number of species of all the points in a given level of landscape complexity. As the number of points was unbalanced, we used a non-parametric species richness estimator (Chao2; Chao and Shen 2004) using SPADE software (Chao and Shen 2010). Beta diversity (species turnover) was calculated as the difference between gamma and mean alpha diversities in each complexity level (Lande 1996). We regressed gamma and mean alpha diversities against landscape complexity to determine whether there are differences in species turnover rates in landscapes with different complexities.

We ran a multi-response permutation procedure (MRPP) and indicator species analysis to determine whether there are differences in the composition of species assemblages in each landscape complexity level and which species determine these differences. For the diversity partition and indicator species analyses, we used all species identified.

As points sampled in two seasons are not independent, we pooled data of both survey years. We summed up bird presence/absence data, and we averaged environmental variables. Thus, the total point used in all analyses was 237. This data pooling was done for CCA, but not for indicator species and biodiversity partition analyses for which the data of each year was studied separately to avoid spurious relations between bird diversity and landscape complexity.

\section{Results}

We recorded a total of 107 bird species, which represents approximately $40 \%$ of cited species for the region (Additional file 1: Table S1) (Narosky and DiGiacomo 1993). Only one, Polystictus pectoralis (Vieillot, 1817), a grassland species, is considered of conservation concern due to habitat loss (Collar and Wege 1995). It was found in very few sites and was not included for the CCA analyses.

Ordination at the local scale shows that species are distributed primarily distinguishing elements such as homestead, trees, and wetland species in the landscape (Figure 2, Table 1). Trees and homesteads are correlated in the landscape as trees are planted to provide shade. The second axis indicates an association with main land use type (cropland, pasture). At the facet scale, the first axis separates species associated to cropland from those associated to landscapes with a greater proportion of pasture cover and of tree elements - accounted by the number and length of tree lines (Figure 3, Table 1). Both ordinations where statistically significant, though they explain a low proportion of the total variance (cumulative variance explained for the two first axes: $5 \%$ at the local scale and $2.8 \%$ at the facet scale).

When nesting habits are identified in the ordination plots, it is clear that this life history attribute explains much of the species association to environmental variables. Both at the local (Figure 4) and facet (Figure 5) scales, species are associated to those elements of the landscape that provide nesting resources. Accordingly, tree and cavity nesting birds were associated to the 


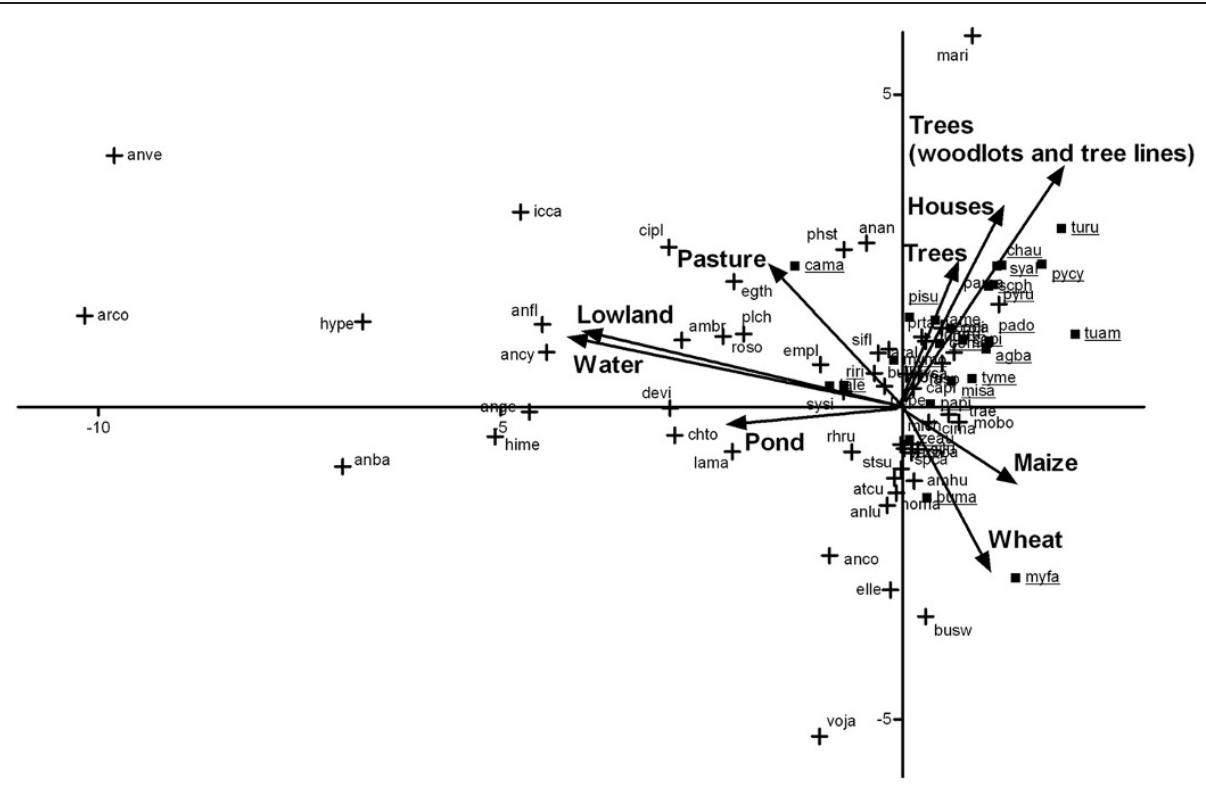

Figure 2 Ordination plot for CCA at local scale. Only variables with the highest interset correlations are drawn. Species are identified using four letter keys (see Additional file 1: Table S1). Species with underlined keys and square symbols are exotic to the Pampas. Ordination explains $5 \%$ of total variance.

presence of homesteads and trees, and riparian vegetation nesting birds are associated to the presence of water bodies and wetland vegetation cover. Noteworthy, many ground nesters were associated to crops, particularly wheat, rather than pastures, as it was expected. The ordinations with trophic habits were statistically significant only at the local scale. Roadside vegetation complexity is in this case an important attribute, and granivorous species are associated to this landscape element (Figure 6, Table 2). Insectivorous and carnivorous species are associated to landscapes with pasture or soybean cover and presence of water bodies and lowlands. Omnivorous

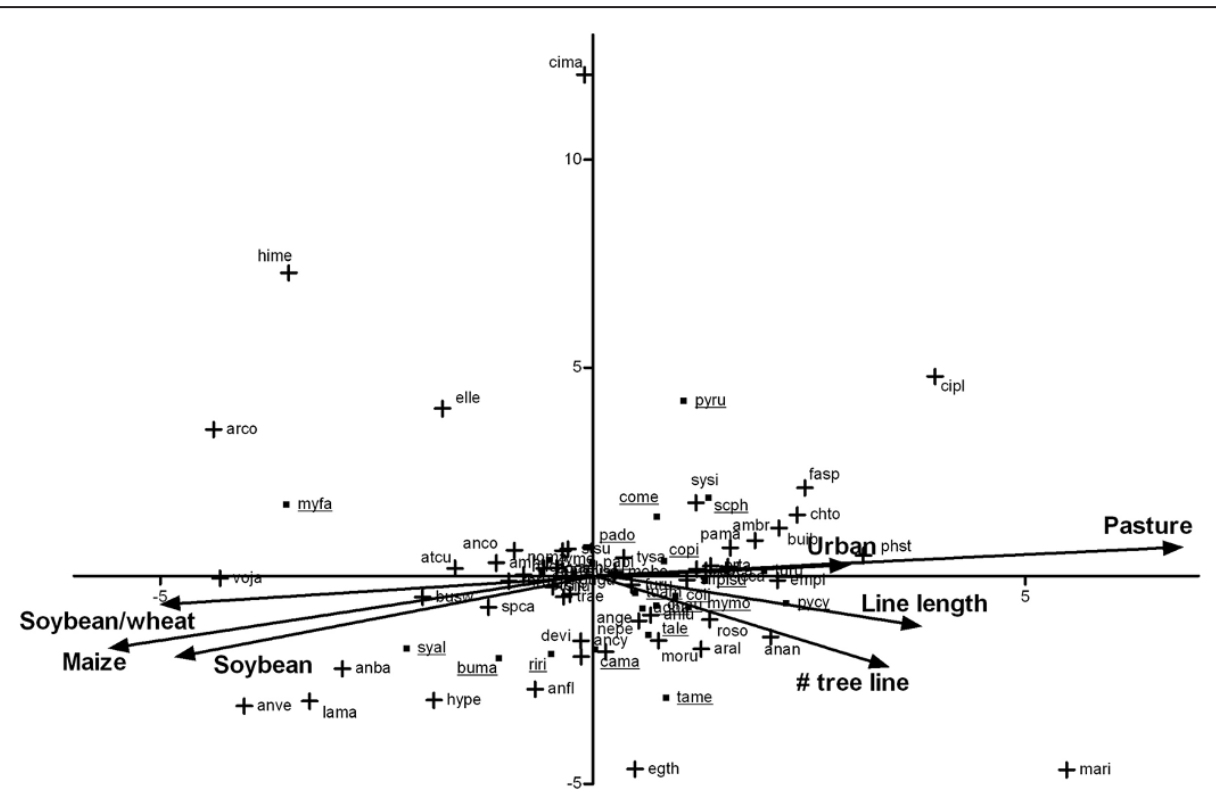

Figure 3 Ordination plot for CCA at facet scale. Only variables with the highest interset correlations are drawn. Species are identified using four letter keys (see Additional file 1: Table S1). Species with underlined keys and square symbols are exotic to the Pampas. Ordination explains $2.8 \%$ of total variance. 


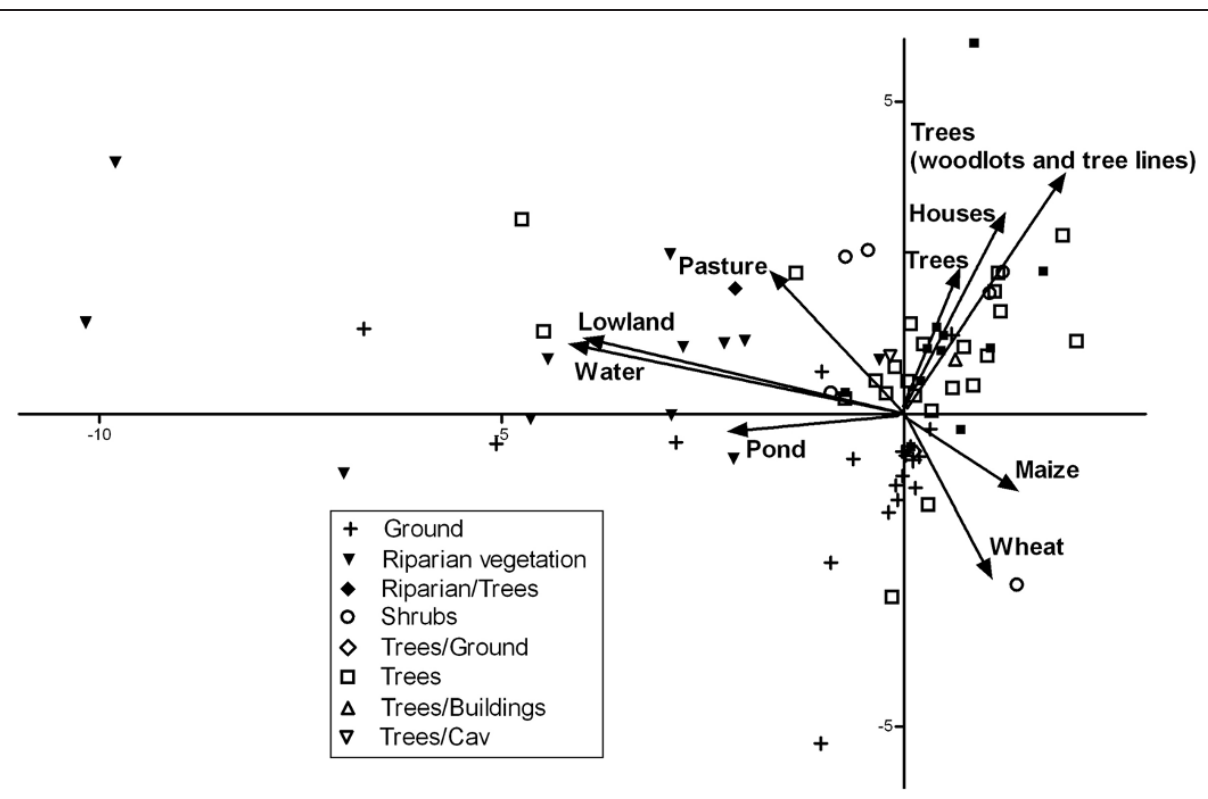

Figure 4 Ordination plot for CCA at local scale with species identified by their nesting habitat.

species are associated to the other most common crops in the region (wheat and maize). The two first axes of this ordination explain $12.4 \%$ of total variance.

The partition of biodiversity components shows that gamma diversity does not vary significantly in a gradient of landscape complexity at the local scale (2007: slope $=$ 2.7, $t=1.01, p=0.35 ; 2008$ : slope $=-2.6, t=-1, p=0.35)$, while mean alpha diversity increases linearly (2007: slope $=0.504, t=5.2, p<0.001 ; 2008:$ slope $=0.942, t=$ $7.85, p<0.001$ ) (Figure 7). This means that simpler landscapes have higher beta diversity, with a higher species turnover among points. On the other hand, MRPP shows that species assemblages differ among landscapes with different complexities (2007: $A=0.019, p<0.001$; 2008: $A=0.016, p<0.001)$. The differences are driven by ten species (10\%), which are associated to landscapes of high levels of complexity (Additional file 2: Table S2).

\section{Discussion}

Our results show that anthropic elements of the landscape as well as land use are important for determining bird distributions and species richness. Furthermore, spatial scale alters the outcome of different landscape configurations on bird assemblage composition, regarding species identity as well as their feeding habits. These

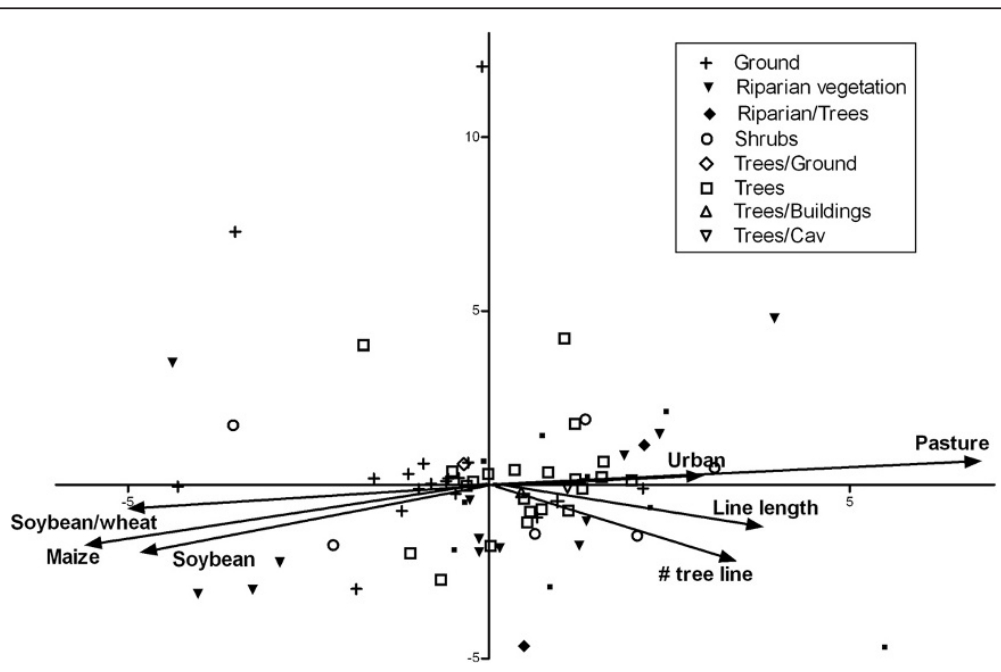

Figure 5 Ordination plot for CCA at facet scale with species identified by their nesting habitat. 


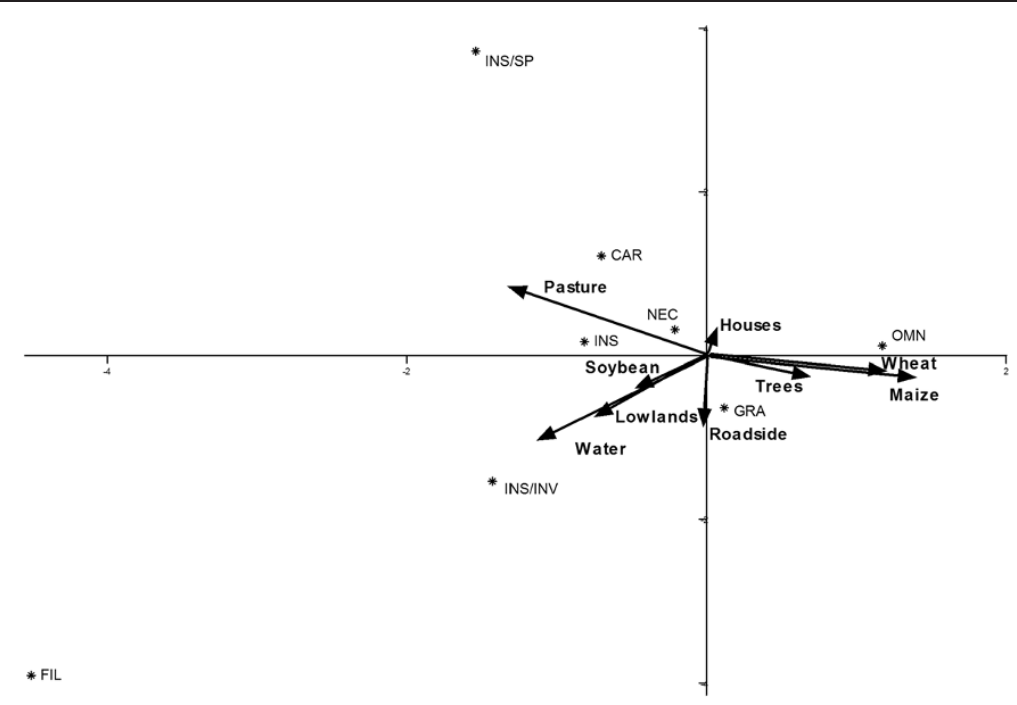

Figure 6 Ordination plot for CCA at local scale of trophic group abundance. Ordination explains $12.4 \%$ of total variance.

are important results to consider when designing management plans as we will discuss in this section.

In the Rolling Pampas agroecosystems, land use type is important for determining bird species distributions, but at the local scale, trees, homesteads, water bodies, and wetland vegetation are of equal importance. Based on our results and those of the previous studies, we conclude that the presence of these elements increases the landscape's capacity for sustaining higher species richness levels (Shnack et al. 2000; Codesido and Bilenca 2011; Weyland et al. 2012), but it is also evident that bird species populations are distributed according to which elements are present. Trees and homesteads favored a group of exotic species to the Pampas, which migrated from the Espinal xerophytic forests and the Delta forests surrounding the region and are now commonly found, such as Mimus saturninus (Lichtenstein, 1823), P. sulphuratus, and Turdus rufiventris Vieillot, 1818. There was an expected association of grassland bird species to pasture cover in the landscape due to its physiognomic similarity to natural grasslands, but a large group of these species was related to annual crop cover (e.g., Nothura maculosa (Temminck, 1815), Rhynchotus rufescens (Temminck, 1815), Athene cunicularia (Molina, 1782), Ammodramus humeralis (Bosc, 1792), and Sturnella superciliaris (Bonaparte, 1851)). Apparently, annual crops are also sustaining some grassland species. It is possible that, under the current no-tillage annual cropping systems in the study area, wheat may offer environmental conditions that are more suitable for grassland birds than pastures because these are usually heavily grazed and disturbed by cattle, increasing the risk of predation and trampling (Cozzani and Zalba 2009). In fact, studies in the region demonstrate that only tall grass pastures support higher species richness, particularly of grassland species (Isacch and Martínez 2001; Filloy and Bellocq 2007; Codesido et al. 2011). Therefore, conditions generated by management of pastures seem to be more important than land use type per se for determining species distributions.

The provision of nesting resources seems to be an important factor for determining species distributions in the study area. In the Pampas, recent studies show that nest site availability is one of the main constraints that may also explain the rarity of some species inhabiting the region (Codesido et al. 2012). The extent and intensity of human alteration of the Rolling Pampas grasslands caused that only species with broad habitat requirements prevail. Indeed, the species that were dropped from our analyses for their low constancy values are those with more specific habitat requirements (like wetland or woodland specialists). Some of them are species of the Espinal and Delta ecoregions, near the limits of their distribution area (like Geothlypis aequinoctialis and Myiodynastes maculatus). These species not only may have low representation in the avifauna but also may have been subsampled in our surveys. Among the less represented species, we also found some grassland specialists (e.g., Embernagra platensis (Gmelin, 1789), Circus buffoni (Gmelin, 1788), Anthus correndera Vieillot, 1818, P. pectoralis, and Cistothorus platensis (Latham, 1790)), showing that these species where in fact the most affected by landscape transformation in the Pampas. In fact, we could not detect many other grassland species of conservation concern like S. defillipii or X. dominicanus (Vieillot, 1823), most probably due to range contraction and local extinctions. Most of the other species identified and included in our analyses are considered habitat generalists (Codesido et al. 2011, 2012). 
Table 2 Interset correlations of variables with axes of CCAs at local scale, considering trophic group abundance

\begin{tabular}{lcc}
\hline Variable & Axis 1 & Axis 2 \\
\hline Wheat cover $^{\mathrm{a}}$ & 0.291 & -0.055 \\
Maize cover $^{\mathrm{a}}$ & 0.332 & -0.06 \\
Pasture cover $^{\mathrm{a}}$ & -0.325 & 0.189 \\
Water (presence/absence) $^{\mathrm{a}}$ & -0.277 & -0.22 \\
Soybean cover $^{\mathrm{a}}$ & -0.113 & -0.098 \\
Lowland cover $^{\mathrm{a}}$ & -0.182 & -0.156 \\
Trees (scattered) $^{\mathrm{a}}$ & 0.077 & -0.131 \\
Roadside complexity $^{\mathrm{a}}$ & -0.01 & -0.198 \\
Houses (presence/absence) $^{\mathrm{a}}$ & 0.015 & 0.074 \\
Wood cover & -0.065 & -0.046 \\
Trees (woodlots and tree lines) & 0.167 & -0.062 \\
Lawn cover $_{\text {Cover richness }}$ & -0.126 & 0.039 \\
Bare soil cover $_{\text {Agriculture cover }}$ & 0.024 & -0.058 \\
Urban cover $_{\text {Stuble cover }}$ & 0.097 & -0.019 \\
Oats cover & 0.039 & -0.019 \\
Pond cover & -0.025 & -0.043 \\
\hline Vaibles that have & 0.166 & 0.01 \\
& -0.077 & -0.073 \\
& -0.077 & -0.056 \\
\hline
\end{tabular}

${ }^{a}$ Variables that have the higher correlations with axes 1 and 2 and are drawn in ordination diagrams in Figure 6.

Their association with environmental variables is generally weak, and this may explain why ordinations, although significant, explain a very low proportion of total variance.

It is argued that agricultural intensification may also deplete bird food supplies, thus determining the distribution of species in the landscape (Weibull and Östman 2003; Codesido et al. 2008; Gavier-Pizarro et al. 2012). Also, because feeding habit is one of the most important ecosystem functions of birds in productive systems (Sekercioglu et al. 2004), studies usually evaluate how landscape characteristics influence the distribution of species according to this trait (see, e.g., Gavier-Pizarro et al. 2012; Apellaniz et al. 2012). Our results show that landscape attributes are important for determining feeding group distributions only at the local scale. Insectivorous and carnivorous species were associated to pastures, water bodies, and soybean crops. Cattle and dung piles attract insects thus favoring insectivorous species. Soybean crops were recently sown when we carried out our surveys. The low vegetation cover may facilitate prey detection for carnivorous species (Leveau and Leveau 2002; Whittingham and Devereux 2008).

The information on how landscape attributes determine the distribution of bird species according to their ecological traits suggests directions to manage species abundance in the region. Not only land use should be considered for management but other landscape elements as well. Our results show that at the local scale, trees are among the most important elements for determining bird species distributions. Studies in the region demonstrate that some of the species favored are crop pests (like Myiopsitta monachus (Boddaert, 1783) or P. picazuro) (Codesido and Bilenca 2011), although our results show that these species are only slightly associated to trees. Differences in the structure or tree species composition of woodlands could explain the differences in their effect on bird distribution. New studies should evaluate what attributes of tree vegetation could be managed to locally exclude crop pest species while conserving the rest.

Other landscape features like water bodies or naturally vegetated roadsides could be managed as well to provide nesting resources to marsh and grassland species, respectively. Our study revealed no effect of roadside vegetation on species distributions, though many other studies demonstrated that they could be suitable places in agroecosystems both for nesting and foraging (Leveau and Leveau 2004; Vickery et al. 2009; Di Giácomo and López de Casenave 2010). We found roadside vegetation complexity was important only for granivorous species. In Pampas agroecosystems, where most grasslands were removed, this landscape feature may become an
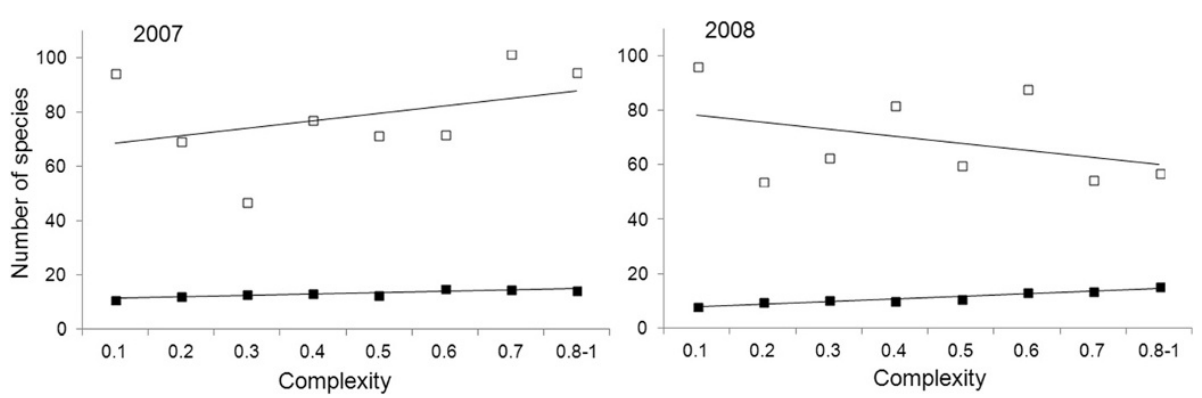

Figure 7 Bird species numbers as a function of landscape complexity at the local scale. Filled squares represent mean alpha diversity, and empty squares gamma diversity. Lines represent least squares regression. 
important source of weed seeds for birds. Roadsides constitute the last grassland relicts, and they are being removed for cropping (Burkart et al. 2011); thus, there is an urgent need to put into practice protection policies of these environments.

The diversity partition analysis showed that simple landscapes have similar gamma diversity as complex landscapes, but higher beta diversity. This means that, in Rolling Pampas agroecosystems, landscape simplification reduces species richness at local scales, but the sum of all types of simple landscapes covers all environmental conditions, thus sustaining the same number and identity of species as complex landscapes at broad spatial scale. The indicator species analysis showed that only a few of the remaining species in the Rolling Pampas are dependent on complex landscapes, while most of them need only the presence of specific landscape elements to cover their needs. Even the indicator species are somehow generalists as revealed by their low indicator values. These results were contrary to our expectations, but they agree with studies evaluating agricultural intensification in European agroecosystems (Flohre et al. 2011). A few elements may have a strong influence on simple landscapes functional differentiation, as each element provides resources for a limited group of species while excluding the rest. For example, as defined in this study, a simple landscape may have a pond but not trees. Thus, it sustains wetland bird species, but not species that nest in trees. This landscape may be complemented by another without water bodies but with trees. As a result, the complete set of species is maintained regionally though locally excluded.

These results have important implications for the interpretation of processes in agroecosystems and management plans. It is imperative to make explicit the spatial scale at which landscape simplification is evaluated. As our results suggest, simplification of agricultural landscapes at local scales may not have a severe impact on bird assemblages as long as the landscape still sustains a large pool of species enabling bird assembling through mass effects, i.e., the occurrence of species outside their core habitats (Schmida and Wilson 1985). That way, species conservation at regional scales is ensured even when local exclusions may occur. Even though, the accretion of local species richness could be hindered by at least two threats: (1) the spatial configuration does not allow site colonization of species from the regional pool, thus population persistence is not ensured, and (2) landscape simplification leads to the same type of landscapes at the local and, in turn, at the regional scale. This unwanted outcome may actually be the case in the Pampas agroecosystem as there is a trend towards agricultural intensification with soybean monoculture (Aizen et al. 2009; Vega et al. 2009). It is nonetheless worth noting that it would be equally detrimental if simplification was driven by the expansion of any other crop monoculture or the removal of landscape elements that provide for functional heterogeneity in the current Rolling Pampas agroecosystem. It is of fundamental importance, then, to maintain and generate landscape heterogeneity for providing suitable conditions for biodiversity.

\section{Conclusions}

Anthropic transformation of ecosystems generates new environmental conditions where the distribution and abundance of biotic elements are altered (Hobbs et al. 2006). In these cases, the management of landscapes to return them to original conditions may not be possible (Seastedt et al. 2008). For this reason, the dichotomy between natural and anthropic landscapes is not useful for conservation and management purposes. Rather, we need to incorporate all features present in the landscape, particularly those that are manageable, whether or not they are of natural or anthropic origin. This may apply to different agroecosystems in the world, but in the case of the Rolling Pampa, this situation is quite evident. In the present, the potential vegetation of the Pampas is a grassland dominated by exotic species, or even a woodland (Burkart et al. 2005; Tognetti et al. 2010). Although trees are exotic, their complete removal is highly improbable due to the cultural attachment to this type of vegetation. The same applies to other anthropic features of the landscape like human settlements and crops. Still, with few exceptions, most studies in the Pampas focus on land use type disregarding other landscape attributes and features that may be of equal importance in determining biodiversity. We do not advocate for planting trees in the Pampas or otherwise promote anthropic landscape change. We argue that conservation efforts need to take a pragmatic approach, and in highly disturbed ecosystems, anthropic elements have to be included as constituent parts of the system. As long as this necessity is incorporated in research and management, more effective biodiversity conservation plans will be developed.

\section{Additional files}

Additional file 1: Table S1. List of species identified in the field surveys. Additional file 2: Table S2. Indicator values according to the indicator species analysis.

Competing interests

The authors declare that they have no competing interests.

\section{Authors' contributions}

FW conducted field work, run statistical analyses and drafted the manuscript. JB assisted with statistical analyses. CMG colaborated with the results and discussion sections and provided comments on the manuscript. All authors read and approved the final manuscript. 


\section{Acknowledgements}

FW was financed by a fellowship of the CONICET and the FONCYT. The ECOS-SECYT A07B04 grant permitted the exchanges between France and Argentina. The final stay in France of FW was made possible through a grant from the French Embassy and the Ministry of Education of Argentina. G. Rocha and P. Moreyra assisted in bird field surveys. Satellite images where provided by the Laboratory of Regional Analysis and Teledetection (LART-FAUBA). S Perelman and A Cerezo gave useful statistical advices.

\section{Author details}

'IFEVA/CONICET - Departamento de Recursos Naturales y Ambiente, Facultad de Agronomía, Universidad de Buenos Aires, Av. 4453, San Martín, Buenos Aires C1417DSE, Argentina. ${ }^{2}$ INRA - SAD Paysage, 65, Rue de Saint Brieuc, CS 84215, Rennes Cedex 35042, France. ${ }^{3}$ Present Address: Grupo de Agroecosistemas y Paisajes Rurales, Recursos Naturales y Gestión Ambiental, INTA - Instituto Nacional de Tecnología Agropecuaria - EEA, Balcarce CC 276, Balcarce 7620, Argentina.

\section{Received: 1 August 2013 Accepted: 6 December 2013}

Published: 26 March 2014

\section{References}

Aizen MA, Garibaldi LA, Dondo M (2009) Expansión de la soja y diversidad de la agricultura argentina. Ecología Austral 19:45-54

Apellaniz M, Bellocq Ml, Filloy J (2012) Bird diversity patterns in neotropical temperate farmlands: the role of environmental factors and trophic groups in the spring and autumn. Austral Ecol 37:547-555

Azpiroz AB, Isacch JP, Dias RA, Giácomo ASD, Fontana CS, Palarea CM (2012) Ecology and conservation of grassland birds in southeastern South America: a review. J Field Ornithol 83:217-246

Baldi G, Paruelo JM (2008) Land-use and land cover dynamics in South American temperate grasslands. Ecol Soc 13:6. http://www.ecologyandsociety.org/ vol13/iss12/art16

Baldi G, Guerschman JP, Paruelo JM (2006) Characterizing fragmentation in temperate South America grasslands. Agr Ecosyst Environ 116:197-208

Batista W (1991) Correspondencia Entre Comunidades Vegetales y Factores Edáficos en el Pastizal de la Pampa Deprimida. Master's thesis. Universidad de Buenos Aires, Argentina

Benton TG, Vickery JA, Wilson JD (2003) Farmland biodiversity: is habitat heterogeneity the key? Trends Ecol Evol 18:182-188

BirdLife International (2010) The BirdLife checklist of the birds of the world, with conservation status and taxonomic sources. Version 3. Downloaded from http://www.birdlife.org/datazone/userfiles/file/Species/Taxonomy/ BirdLife_Checklist_Version_3.zip

Burkart SE, Garbulsky MF, Ghersa CM, Guerschman JP, León RJC, Oesterheld M, Paruelo JM, Perelman SB (2005) Las Comunidades Potenciales Del Pastizal Pampeano Bonaerense. In: Oesterheld M, Aguiar MR, Ghersa CM, Paruelo JM (ed) La Heterogeneidad De La Vegetación En Los Agroecosistemas. Editorial Facultad de Agronomía, Buenos Aires, pp 379-399

Burkart S, León R, Conde M, Perelman S (2011) Plant species diversity in remnant grasslands on arable soils in the cropping Pampa. Plant Ecol 212:1009-1024

Cerezo A, Conde MC, Poggio S (2011) Pasture area and landscape heterogeneity are key determinants of bird diversity in intensively managed farmland. Biodivers Conserv 20:2649-2667

Chaneton EJ, Mazía N, Batista W, Rolhauser AG, Ghersa CM (2012) Woody plant invasions in Pampa grasslands: a biogeographical and community assembly perspective. In: Myster RW (ed) Ecotones between forest and grassland. Springer, New York

Chao A, Shen T-J (2004) Nonparametric prediction in species sampling. J Agric Biol Environ Stat 9:253-269

Chao A, Shen T-J (2010) Program SPADE (Species Prediction and Diversity Estimation). Program and user's guide. http://chao.stat.nthu.edu.tw. Accessed 01 Jun 2010

Chapin FS, Zabaleta ES, Eviner VT, Naylor RL, Vitousek PM, Reynolds HL, Hooper DU, Lavorel S, Sala OE, Hobbie SE, Mack MC, Díaz S (2000) Consequences of changing biodiversity. Nature 405:234-242

Codesido M, Bilenca D (2011) Respuesta De La Riqueza De Aves Terrestres A Los Usos De La Tierra En La Provincia De Buenos Aires. In: Laterra P, Jobbágy E, Paruelo J (ed) Valoración De Servicios Ecosistémicos: Conceptos, Herramientas Y Aplicaciones Para El Ordenamiento Territorial. Ediciones INTA, Buenos Aires
Codesido M, Fischer CG, Bilenca D (2008) Asociaciones entre diferentes patrones de uso de la tierra y ensambles de aves en agroecosistemas de la Región Pampeana, Argentina. Ornitol Neotrop 19:575-585

Codesido M, González-Fischer C, Bilenca D (2011) Distributional changes of landbird species in agroecosystems of central Argentina. Condor 113:266-273

Codesido M, González-Fischer C, Bilenca D (2012) Agricultural land-use, avian nesting and rarity in the Pampas of central Argentina. Emu 112:46-54

Collar NJ, Wege DC (1995) The distribution and conservation status of the bearded tachuri Polystictus pectoralis. Bird Conserv Int 5:367-390

Comparatore VM, Martínez MM, Vassallo Al, Barg M, Isacch JP (1996) Abundancia y relaciones con el hábitat de aves y mamíferos en pastizales de Paspalum quadrifarium (paja colorada) manejados con fuego (provincia de Buenos Aires, Argentina). Interciencia 21:228-237

Cozzani N, Zalba SM (2009) Estructura de la vegetación y selección de hábitats reproductivos en aves del pastizal pampeano. Ecología Austral 19:35-44

de la Peña MR (1992) Guía de aves argentinas. Segunda Edición (Tomos I al V). L.O.L.A, Buenos Aires

Di Giácomo AS, López De Casenave J (2010) Use and importance of crop and field margin habitats for birds in a neotropical agricultural ecosystem. Condor 112:283-293

Faggi AM, Krellenberg K, Castro R, Arriaga M, Endlicher W (2006) Biodiversity in the Argentinean Rolling Pampa ecoregion: changes caused by agriculture and urbanisation. Erdkunde 60:127-138

Farnsworth GL, Pollock KH, Nichols JD, Simons TR, Hines JE, Sauer JR (2002) A removal model for estimating detection probabilities from point-count surveys. Auk 119:414-425

Filloy J, Bellocg MI (2007) Patterns of bird abundance along the agricultural gradient of the Pampean region. Agr Ecosyst Environ 120:291-298

Fleishman E, Betrus CJ, Blair RB (2003) Effects of spatial scale and taxonomic group on partitioning of butterfly and bird diversity in the Great Basin, USA. Landscape Ecol 18:675-685

Flohre A, Fischer C, Aavik T, Bengtsson J, Berendse F, Bommarco R, Ceryngier P, Clement LW, Dennis C, Eggers S, Emmerson M, Geiger F, Guerrero I, Hawro V, Inchausti P, Liira J, Morales MB, Oñate JJ, Pärt T, Weisser WW, Winqvist C, Thies C, Tscharntke T (2011) Agricultural intensification and biodiversity partitioning in European landscapes comparing plants, carabids, and birds. Ecol Appl 21:1772-1781

Gabelli FB, Fernández GJ, Ferretti V, Posse G, Coconier E, Gavieiro HJ, Llambías PE, Peláez PI, Vallés ML, Tubaro PL (2004) Range contraction of the pampas meadowlark Sturnella defilippii in the southern pampas grasslands of Argentina. Oryx 38:1-7

Garaffa Pl, Filloy J, Bellocq MI (2009) Bird community responses along urban-rural gradients: does the size of the urbanized area matter? Land Urban Plan 90:33-41

Gavier-Pizarro Gl, Calamari NC, Thompson JJ, Canavelli SB, Solari LM, Decarre J, Goijman AP, Suarez RP, Bernardos JN, Zaccagnini ME (2012) Expansion and intensification of row crop agriculture in the Pampas and Espinal of Argentina can reduce ecosystem service provision by changing avian density. Agr Ecosyst Environ 154:44-55

Gering JC, Crist TO, Veech JA (2003) Additive partitioning of species diversity across multiple spatial scales: implications for regional conservation of biodiversity. Conserv Biol 17:488-499

Ghersa CM, León RJC (2001) Ecología Del Paisaje Pampeano: Consideraciones Para Su Manejo Y Conservación. In: Naveh Z, Lieberman AS (ed) Ecología de Paisajes. Editorial Facultad de Agronomía, Buenos Aires, pp 471-512

Ghersa CM, De la Fuente E, Suarez S, Leon RJ (2002) Woody species invasion in the Rolling Pampa grasslands, Argentina. Agr Ecosyst Environ 88:271-278

Hobbs RJ, Arico S, Aronson J, Baron JS, Bridgewater P, Cramer VA, Epstein PR, Ewel JJ, Klink CA, Lugo AE, Norton D, Ojima D, Richardson DM, Sanderson EW, Valladares F, Vilà M, Zamora R, Zobel M (2006) Novel ecosystems: theoretical and management aspects of the new ecological world order. Global Ecol Biogeog 15:1-7

Isacch JP, Martínez MM (2001) Estacionalidad y relaciones con la estructura del habitat de la comunidad de aves de pastizales de paja colorada (Paspalum quadrifarium) manejados con fuego en la Provincia de Buenos Aires, Argentina. Ornitol Neotrop 12:345-354

Krapovickas SK, Di Giacomo AS (1998) Conservation of pampas and Campos grasslands in Argentina. Parks 8:47-53

Lande R (1996) Statistics and partitioning of species diversity, and similarity among multiple communities. OIKOS 76:5-13

Leveau LM, Leveau CM (2002) Uso de hábitat por aves rapaces en un agroecosistema pampeano. Hornero 17:9-15

Leveau LM, Leveau CM (2004) Riqueza y abundancia de aves en agroecosistemas pampeanos durante el período post-reproductivo. Ornitol Neotrop 15:371-380 
Leveau CM, Leveau LM (2005) Avian community response to urbanization in the Pampean region, Argentina. Ornitol Neotrop 16:503-510

MDAYP (2010) Estimaciones Agrícolas Para La Campaña 2009-10. http://www.siia. gov.ar. Accessed 01 Jun 2010

Medan D, Torretta JP, Hodara K, De la Fuente E, Montaldo NH (2011) Effects of agriculture expansion and intensification on the vertebrate and invertebrate diversity in the Pampas of Argentina. Biodivers Conserv 20:3077-3100

Narosky T, Digiacomo AG (1993) Las aves de la Provincia de Buenos Aires: distribución y estatus. Buenos Aires, Asoc. Ornitológica del Plata, Vázquez Mazzini Ed. and L.O.LA

Pimentel D, Stachow U, Takacs DA, Brubaker HW, Dumas AR, Meaney JJ, O'Neil JAS, Onsi DE, Corzilius DB (1992) Conserving biological diversity in agricultural/forestry systems. Bioscience 42:354-362

Poggio SL, Chaneton EJ, Ghersa CM (2010) Landscape complexity differentially affects alpha, beta, and gamma diversities of plants occurring in fencerows and crop fields. Biol Conserv 143:2477-2486

Ralph CJ, Sauer JR, Droege S (1995) Monitoring bird populations by point counts. Albany, CA: Pacific Southwest Research Station, Forest Service, US Department of Agriculture. Gen Tech Rep. PSW-GTR-149

Schmida A, Wilson MV (1985) Biological determinants of species diversity. J Biogeogr 12:1-20

Schrag AM, Zaccagnini ME, Calamari N, Canavelli S (2009) Climate and land-use influences on avifauna in central Argentina: broad-scale patterns and implications of agricultural conversion for biodiversity. Agr Ecosyst Environ 132:135-142

Seastedt TR, Hobbs RJ, Suding KN (2008) Management of novel ecosystems: are novel approaches required? Front Ecol Environ 6:547-553

Sekercioglu CH (2006) Increasing awareness of avian ecological function. Trends Ecol Evol 21:464-471

Sekercioglu CH, Daily GC, Ehrlich PR (2004) Ecosystem consequences of bird declines. Proc Natl Acad Sci USA 101:18042-18047

Shnack JA, Francesco FOD, Colado UR, Novoa ML, Schnack EJ (2000) Humedales antrópicos: su contribución para la conservación de la biodiversidad en los dominios subtropical y pampásico de la Argentina. Ecología Austral 10:63-80

Soriano A (1991) Rio de la Plata grasslands. In: Coupland RT (Ed.) Natural grasslands. Introduction and Western Hemisphere. Elsevier, Amsterdam, The Netherlands, pp 367-407

Suárez SA, Ghersa CM, De la Fuente E, León RJC (2000) Shifts of floristic groups in cropland communities of the Pampas during 1926 to 1999. In: Third International Weed Science Congress, Foz do Iguassu

Tognetti PM, Chaneton EJ, Omacini M, Trebino HJ, León RJC (2010) Exotic vs. native plant dominance over 20 years of old-field succession on set-aside farmland in Argentina. Biol Conserv 143:2494-2503

Tscharntke T, Klein AM, Kruess A, Steffan-Dewenter I, Thies C (2005) Landscape perspectives on agricultural intensification and biodiversity - ecosystem service management. Ecol Lett 8:857-874

Vega E, Baldi G, Jobbagy EG, Paruelo J (2009) Land use change patterns in the Río de la Plata grasslands: the influence of phytogeographic and political boundaries. Agr Ecosyst Environ 134:287-292

Vickery JA, Feber RE, Fuller RJ (2009) Arable field margins managed for biodiversity conservation: a review of food resource provision for farmland birds. Agr Ecosyst Environ 133:1-13

Weibull AC, Östman O (2003) Species composition in agroecosystems: the effect of landscape, habitat, and farm management. Basic Appl Ecol 4:349-361

Weyland F, Baudry J, Ghersa C (2012) A fuzzy logic method to assess the relationship between landscape patterns and bird richness of the Rolling Pampas. Landscape Ecol 27:869-885

Whittingham MJ, Devereux CL (2008) Changing grass height alters foraging site selection by wintering farmland birds. Basic Appl Ecol 9:779-788

Zalba SM, Villamil CB (2002) Woody plant invasion in relictual grasslands. Biol Invasions 4:55-72

Zipping C (1958) The removal method of population estimation. J Wildlife Manage 22:82-90

Zonneveld IS (1989) The land unit - a fundamental concept in landscape ecology, and its applications. Landscape Ecol 3:67-86

doi:10.1186/0717-6317-87-1

Cite this article as: Weyland et al:: Rolling Pampas agroecosystem: which landscape attributes are relevant for determining bird distributions? Revista Chilena de Historia Natural 2014 87:1. 